\title{
Development of eggs and the planktonic stages of salmon lice (Lepeophtheirus salmonis) at low temperatures
}

\author{
Karin Boxaspen \& Tore Næss \\ Institute of Marine Research, Austevoll Aquaculture Research Station, N-5392 Storebø, Norway
}

Keywords: salmon lice, low temperature, development of early life stages

\begin{abstract}
To verify if and to what extent egg and nauplii development of the salmon lice take place during winter, the development from egg to the copepodid stage at $2,3,4,5$ and $10^{\circ} \mathrm{C}$ was examined. Newly extruded egg strings from a winter population of salmon lice were individually placed in $6 \mathrm{ml}$ stagnant hatehing systems. Initially, no significant differences in egg development time were found between these and larger aerated systems, though a tendency for less synchronised hatching of the total egg string was detected in the stagnant systems (difference $<12 \mathrm{~h}$ ). In light versus dark conditions the time to hatching was significantly prolonged by darkness (10-15\%). The use of small stagnant experimental units was a pronounced simplification of hatching methods used earlier. At low temperature all but one pair of egg strings hatched. Time to first hatching was found to be $45.1 \pm 0.5$ days at $2^{\circ} \mathrm{C}, 35.2 \pm 0.4$ days at $3^{\circ} \mathrm{C}, 27.6 \pm 0.2$ days at $4^{\circ} \mathrm{C}, 21.6 \pm 0.1$ days at $5^{\circ} \mathrm{C}$ and $8.7 \pm 0.1$ days at $10^{\circ} \mathrm{C}$. The developmental time to hatching correlated to temperature fitted the polynomial function: Days to first hatching $=0.6638 \mathrm{~T}^{2}-12.492 \mathrm{~T}$ $+67.116\left(R^{2}=0.99\right)$. A high proportion of the nauplii developed to the copepodid (infectious stage) stage at $4^{\circ} \mathrm{C}$ and higher but only a small proportion at 2 and $3^{\circ} \mathrm{C}$. Total developmental time to copepodid ranged from 12.7 days at $10^{\circ} \mathrm{C}$ to 68.5 days at $2{ }^{\circ} \mathrm{C}$ or to the polynomial function Days to first copepodid $=$ $1.0236 \mathrm{~T}^{-2}-19.129 \mathrm{~T}+101.5\left(\mathrm{R}^{2}=0.995\right)$. The ephysiological agen at hatching, i.e. the product of days and the respective temperature, showed not to be linearly correlated to temperature, but showed a maximum at $4^{\circ} \mathrm{C}$. Average age at hatching was $90^{\circ}$ days at $2^{\circ} \mathrm{C}$ and $110^{\circ}$ days at $4^{\circ} \mathrm{C}$. Thus the egg strings of the winter population appeared to be adapted to very low temperature by reducing the time for egg development. The present results show that eggs of salmon lice can develop to the infectious stage during winter along the Norwegian west coast.
\end{abstract}

\section{Contents}

Introduction

Material and methods $\begin{array}{lr}\text { Egg string collection } & 52 \\ \text { Water quality } & 52 \\ \text { Development of hatching systems } & 52 \\ \text { Method experiment 1: aeration and volume of } & \\ \quad \text { experimental units } & 52 \\ \quad \text { Method experiment 2: light versus dark conditions } & 53 \\ \text { Low temperature experiments: hatching, nauplii } & \\ \quad \text { and first copepodids } & 53 \\ \text { Results } & 53 \\ \text { Discussion } & 54 \\ \text { Acknowledgements } & 55 \\ \text { References } & 55\end{array}$

\section{Introduction}

While bacterial diseases like Furunculosis and cold water Vibriosis have been successfully reduced by development and rigorous use of vaccines, salmon lice are still a major problem effecting salmon farming in Norway. Total losses due to salmon lice have been calculated to be between 200 and 500 mill NOK every year (Maroni et al., 1994). Salmon lice are also a major problem in other salmon producing countries such as Ireland, Scotland and Shetland and Canada (Wootten, 1982; Pike, 1989; Hogans \& Trudeau, 1989; Costello, 1993; Jackson \& Minchin, 1993).

The life cycle of salmon lice consists of 10 life stages with each separated by a moult. The first two stages are the nauplii, which are planktonic and non-feeding. Following the naupliar stages there is a single infectious copepodid stage which is also planktonic and non-feeding until it locates a host "(Kabata, 1979; Johnson \& Albright, 1991). Following the copepodid stage there are four attached 
chalimus stages, two free-moving preadults and an adult stage (Kabata, 1979; Johnson \& Albright, 1991; Schram, 1993). Development for all stages has been reported to occur between $5-22^{\circ} \mathrm{C}$ (Wootten et al., 1982; Johannesen, 1978; Tully, 1989; Johnson \& Albright, 1991). Egg strings are reported to hatch over a temperature range of $5-16^{\circ} \mathrm{C}$ when the ovigerous females had been acclimatised in $9^{\circ} \mathrm{C}$ (Johannesen, 1978).

It is not until recent years that severe problems with salmon lice înfections during winter have been reported by Norwegian salmon farmers and few reports are available on lice development at low temperatures. Boxaspen (1997) found that the abundance of lice was positively correlated to sea water temperatures during the winter months, but reported infections on fish also below $5^{\circ} \mathrm{C}$. In Norwegian coastal waters the sea water temperature can in some years be close to zero $\left({ }^{\circ} \mathrm{C}\right)$. It is therefore relevant to question: Do salmon lice reproduce and develop at these low temperatures? The objective of this study was therefore to assess to what extent egg and naupliar development takes place at temperatures below $5^{\circ} \mathrm{C}$.

Several authors have described hatching systems for both Lepeophtheirus salmonis (Johannesen, 1978; Johnson \& Albright, 1991; Jackson et al., 1994) and Caligus elongatus (Pike et al., 1993). These have all been systems with either flow through or aeration or both, and with volumes ranging from $100 \mathrm{ml}$ to $45 \mathrm{~L}$. In the present study we show that small polystyrene dishes with six $10 \mathrm{ml}$ wells could be used. Similar systems were used by Bergh et al. (1992) in experiments with individual fish larvae.

\section{Material and methods}

\section{Egg string collection}

In the first experiments salmon lice were collected from Atlantic salmon reared in net-pens. Ovigerous female lice with both egg strings intact were removed and put into autoclaved sea water (see below). Egg strings were removed if necessary by cutting them from the female with a scalpel. Viability of egg strings was determined following the method of Ritchie et al. (1993). Briefly, egg strings were examined using dissecting microscope and only those pairs of egg strings where both were opaque with symmetrically stacked eggs were regarded as viable. Egg strings that totally lacked the black pigmentation found in more mature egg strings were regarded as newly extruded.

In the later experiments egg strings of known age were obtained as follows: infected Atlantic salmon were anaesthetised and all salmon lice except for pairs in precopulae and virgin females were removed. These salmon were then transferred to indoor tanks $\left(2 \mathrm{~m}^{3}\right)$ and examined twice a day for the presence of ovigerous females. When egg strings were observed the salmon was anaesthetised and the female removed. All pairs of egg strings were thus the first eggs from each female louse. Egg strings were then transferred to individual hatching systems.

\section{Water quality}

To control microbial activity in the hatching systems two sorts of pre treated sea water were used. In the preliminary trials sand filtered autoclaved sea water adjusted to $80 \%$ salinity before heat treatment, was used. For the main trial we chose sand filtered microbially matured sea water after the method of Skjermo et al. (1997). The benefit of the so called «aged» water is that slow growing bacteria, thought to be benign, will dominate the flora and as such prevent the development of other bacteria. Ambient sea water salinity was $34.0 \pm 0.5$ ppt.

\section{Development of hatching systems}

All experiments were conducted under static conditions using filtered and either autoclaved or aged sea water.

Method experiment 1: Aeration and volume of experimental units

In our preliminary trials we examined the effect of aeration and container volume on the hatching success of egg strings at 5 and $10^{\circ} \mathrm{C}$ (Table I). The system with aeration was made up of $250 \mathrm{ml}$ plastic bottles, placed up side down with the bottom removed. Aeration was provided by two aquarium 
Table 1. Hatching success of Lepeophtheirus salmonis egg strings in different experimental units relative to volume and aeration ( $n=6$ in all experiments).

\begin{tabular}{lllll}
\hline $\begin{array}{l}\text { Volume } \\
(\mathrm{ml})\end{array}$ & Unit & Aeration & $\begin{array}{l}\text { Tempera- } \\
\text { ture } \\
\left({ }^{\circ} \mathrm{C}\right)\end{array}$ & $\begin{array}{l}\text { Hatching } \\
(\%)\end{array}$ \\
\hline 150 & Flasks & + & 10 & 100 \\
150 & Flasks & + & 5 & 100 \\
30 & Petri dish & - & 10 & 100 \\
10 & Multiwell dishes & - & 10 & 100 \\
10 & Multiwell dishes & - & 5 & 100 \\
\hline
\end{tabular}

pumps with the air being introduced into the system through the mouth of the bottle. Each bottle was filled with $150 \mathrm{ml}$ of autoclaved sea water. For units without aeration, traditional petri dishes $(30 \mathrm{ml})$ were initially tried. Six pairs of egg strings were used with one string of each pair placed individually in each of the culture vessels. Temperature was maintained at $10^{\circ} \mathrm{C}$. A similar experiment was conducted at $5^{\circ} \mathrm{C}$ using polystyrene dishes with six wells $(10 \mathrm{ml})$ (Nunc, Roskilde, Denmark) instead of petri dishes. All egg strings were examined three times a day until hatching.

Since there were no significant differences in hatching success between containers with and without aeration or between petri dishes or Nunc multiwell dishes (Table I), we chose to use Nunc trays without aeration for our subsequent studies.

Method experiment 2: Light versus dark conditions

Twelve ovigerous salmon lice were collected from Atlantic salmon in net-pens. Egg strings were transferred into Nunc trays containing $6 \mathrm{ml}$ of autoclaved sea water with one of each pair of egg strings being incubated in darkness, and the other under $24 \mathrm{~h}$ light. Egg strings were incubated at $10^{\circ} \mathrm{C}$ and examined three times a day for hatching.

\section{Low temperature experiments: hatching, nauplii and first copepodids}

Egg strings were obtained from copepods on Atlantic salmon being held in indoor tanks at $6.8 \pm 0.1{ }^{\circ} \mathrm{C}$. For each temperature tested $(2,3,4$ and $5^{\circ} \mathrm{C}$ ) one of each of twelve pairs of egg strings were incubated at the test temperature and the other at $10^{\circ} \mathrm{C}$ as a control. The eggs were examined three times a day and the time of hatching and the appearance of the copepodid stage registered. Matured sea water was used. The temperatures during the experiment were stable at $2.01 \pm 0.01$, $3.01 \pm 0.02,3.98 \pm 0.04$ and $4.99 \pm 0.02{ }^{\circ} \mathrm{C}$ respectively (Temperature $\pm \mathrm{SE}$ ).

\section{Results}

All egg strings in light and darkness hatched. A small, but significant ( $t$-test, paired comparisons, $p>0.05$ ) prolonged time to first registration of hatching was found in darkness (Fig. 1a). This tendency was more pronounced in time to hatching of the whole egg string (Fig. 1b).

In the low temperature experiments, all but one pair of strings from $5^{\circ} \mathrm{C}$ and the control hatched. Time to first hatching was found to be $45.1 \pm 0.5$ days at $2^{\circ} \mathrm{C}, 35.2 \pm 0.4$ days at $3^{\circ} \mathrm{C}, 27.6 \pm 0.2$ days at $4^{\circ} \mathrm{C}, 21.6 \pm 0.1$ days at $5^{\circ} \mathrm{C}$ and $8.7 \pm 0.1$ days at $10^{\circ} \mathrm{C}$ (Fig. 2). The developmental time correlated to temperature fitted the polynomial function: Time
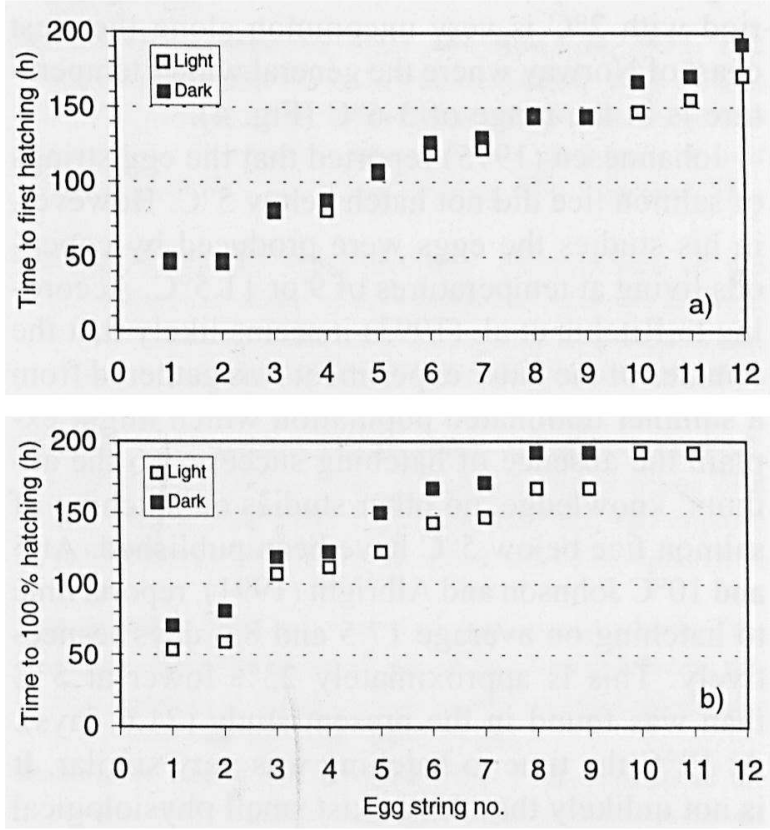

Fig. 1. Differences between time to first hatching (a) and time - to complete hatching (b) of Lepeophtheirus salmonis egg strings maintained under conditions of total darkness (dark box) and 24 hours light (open box). Eggs were incubated at $10^{\circ} \mathrm{C}$ and ambient salinity under static conditions. 
to first hatching $=0.6255 \mathrm{~T}^{2}-11.993 \mathrm{~T}+66.039$ $\left(\mathrm{R}^{2}=0.99\right)$. Copepodids were obtained from $25 \%$ of the egg strings reared at $2^{\circ} \mathrm{C}, 42 \%$ of the egg strings at $3^{\circ} \mathrm{C}, 100 \%$ at $4^{\circ} \mathrm{C}$ and $75 \%$ at $5^{\circ} \mathrm{C}$. All egg strings at $10^{\circ} \mathrm{C}$ except one produced copepodids. For 2 and $3^{\circ} \mathrm{C}$ only few animals were produced from each of the strings hatching. Total developmental time to copepodid ranged from 12.7 days at $10^{\circ} \mathrm{C}$ to 68.5 days at $2^{\circ} \mathrm{C}$ (Fig. 2). The data fitted the polynomial equation Days to first copepodid $=1.0236 \mathrm{~T}^{-2}-19.129 \mathrm{~T}+101.5\left(\mathrm{R}^{2}=0.995\right)$.

\section{Discussion}

In this study, eggs from cold $\left(6.8^{\circ} \mathrm{C}\right)$ adapted $L$. salmonis hatched and developed to the infectious copepodid stage at temperatures as low as $2^{\circ} \mathrm{C}$. This suggests that development and hatching of the eggs of this species can occur throughout the winter. This is supported by the presence of copepodids and ovigerous females on net-pen reared salmon in Norwegian waters during periods of low water temperature (Boxaspen, 1997). However, development from the egg to the infectious copepodid stage takes up to 2 months at $2^{\circ} \mathrm{C}$. Such long period with $2^{\circ} \mathrm{C}$ is very uncommon along the west coast of Norway where the general winter temperature is in the range of $3-6^{\circ} \mathrm{C}$ (Fig. 4).

Johannesen (1975) reported that the egg strings of salmon lice did not hatch below $5^{\circ} \mathrm{C}$. However, in his studies the eggs were produced by copepods living at temperatures of 9 or $11.5^{\circ} \mathrm{C}$. According to Ritchie et al. (1993) it seems likely that the females of the latter experiment was gathered from a summer dominated population which might explain the absence of hatching success. To the authors' knowledge, no other studies on hatching of salmon lice below $5^{\circ} \mathrm{C}$ have been published. At 5 and $10^{\circ} \mathrm{C}$ Johnson and Albright (1991), reports time to hatching on average 17.5 and 8.6 days respectively. This is approximately $23 \%$ lower at $5^{\circ} \mathrm{C}$ than was found in the present study (21.6 days). At $10^{\circ} \mathrm{C}$ the time to hatching was very similar. It is not unlikely that there exist small physiological differences between louse populations from the Canadian west coast (Johnson and Albright, 1991) and the eastern Atlantic. However, due to the use of darkness during egg development in our experi-

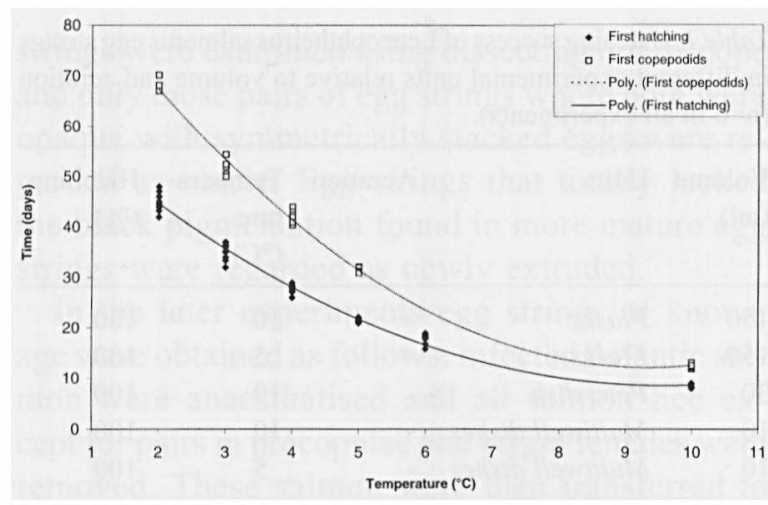

Fig. 2. Time to first hatching of Lepeophtheirus salmonis egg strings (dark box) and time to first appearance of the copepodid stage (open box). Eggs and nauplii were maintained in darkness at various temperatures and ambient salinity. Lines are the fitted polynomial functions, Time to first hatching $=0.6255 \mathrm{~T}^{2}-11.993 \mathrm{~T}$ $+66.039\left(R^{2}=0.99\right)$ (whole line) and Days to first copepodid = $1.0236 \mathrm{~T}^{-2}-19.129 \mathrm{~T}+10 \mathrm{I} .5\left(\mathrm{R}^{2}=0.995\right)$ (punctuated line).

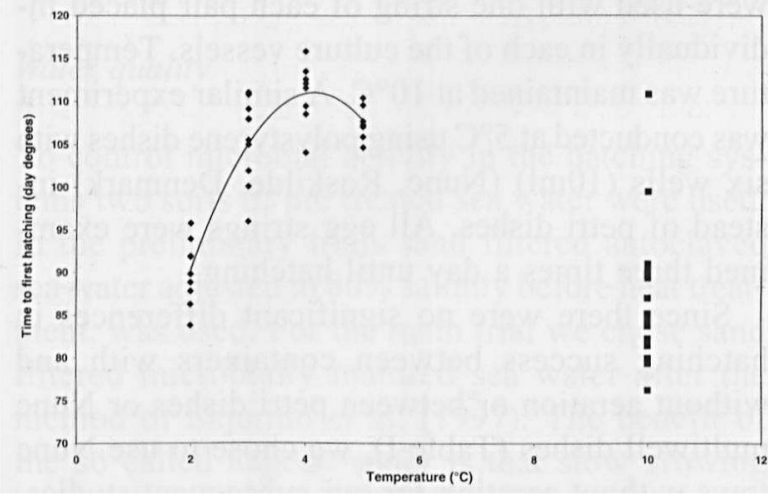

Fig. 3. Time to first hatching of Lepeophtheirus salmonis egg strings measured in day degrees (i.e. the product of days and the respective temperature). Each point represents one egg string.

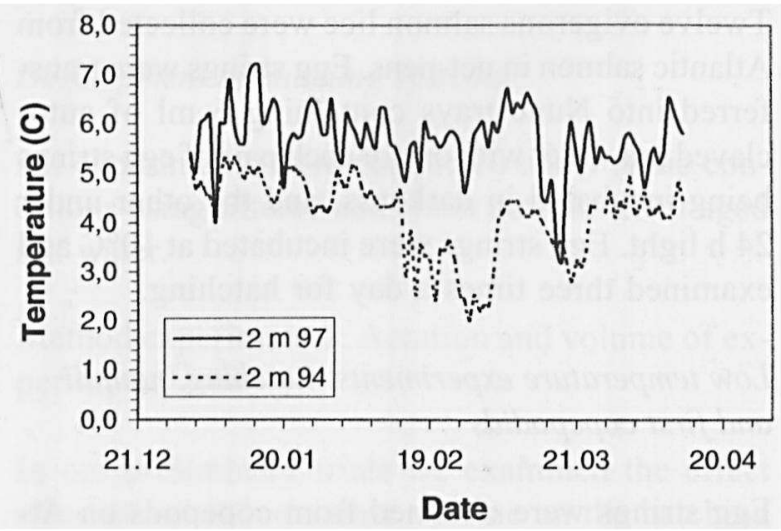

Fig. 4. Temperature development at $2 \mathrm{~m}$ depth in the net-pens at Austevoll Aquaculture Research Station. Temperatures are given for 1994 (punctuated line), an unusual cold winter, and the year of the study (whole line). 
ments, a prolonged time to hatching was expected. This was found to be $10-15 \%$ at $10^{\circ} \mathrm{C}$ (cf. Fig. 1). The presented numbers for nauplii and copepodid developmental times and thereby the fitted functions are therefore most probably higher than real values.

The lack of success in producing copepodids below $4^{\circ} \mathrm{C}$ could be an effect of low temperature. However the use of small containers in this study may also have effected these results. Further study is required to determine both survival to the copepodid stage and the infectivity of copepodids produced at low temperatures.

A way to present the physiological age of the eggs at hatching is to calculate the degree days at hatching, i.e. the product of days and the respective temperature (C). A plot of this showed that the uphysiological age» of the eggs was not linearly correlated to temperature, but showed a maximum at $4^{\circ} \mathrm{C}$ (Fig. 3). Average time to first hatching ranged from 90.16 day degrees at $2^{\circ} \mathrm{C}$ to 110.59 day degrees at $4^{\circ} \mathrm{C}$. Thus the egg strings of the winter population appeared to be adapted to very low temperature by reducing the time for egg development.

\section{Acknowledgements}

This project was funded by the Norwegian Research Council under project no. 110647/120. A special thanks to our assistant Audhild Kårdal, for invaluable help and dedication, working with small things like salmon lice, Dr. Jens Chr. Holm for commenting on the manuscript and to an anonymous reviewer for valuable and very comprehensive comments.

\section{References}

Bergh Ø, Hansen GE, Taxt RE. 1992. Experimental infection of eggs and yolk sac larvae of halibut, Hippoglossus hippoglossus L. J, Fish Dis. I5: 379-391.

Boxaspen K. 1997. Geographical and temporal variation in abundance of salmon lice (Lepeophtheirus salmonis) on salmon (Salmo salar L.). ICES J. Marine Sci. 54:1144-1147.

Costello M. 1993. Controlling sea-lice infestations on farmed salmon in northern Europe: Options and the use of cleaner fish. World Aquaculture 24(1): 49-55.

Hogans WE, Trudeau DJ. 1989. Preliminary studies on the biology of sea lice, Caligus elongatus, Caligus curtus and
Lepeophtheirus salmonis (Copepoda:Caligoida) parasitic on cage-cultured salmonids in the lower bay of Fundy, Can. Tech. Rep. Fish. Aquatic Sciences 1715: 1-14.

Jackson D, Minchin D. 1993. Variation in sea lice levels on farmed salmonids in Ireland, ICES, Mariculture Committee F:30: 1-6.

Jackson D, Minchin D, Duggan C, Hassett P, Leahy Y, Whitaker A. 1994. Observations on the larval stages of the salmon louse, Lepeophtheirus salmonis. ICES, Mariculture Conmittee F 14: 1-5.

Johannesen A. 1975. Salmon lice, free living larval stages, growth and infection on salmon (Salmo salar L.) from farmed and commercially caught fish in western Norway 1973-1974. MSc thesis, Norwegian College of Fisheries, University of Bergen, Norway (In Norwegian): 1-113.

Johannesen A. 1978. Early stages of Lepeophtheirus salmonis (Copepoda: Caligidae). Sarsia, 63:169-176.

Johnson SC, L. J. Albright LJ. 1991. Development, growth and survival of Lepeophtheirus salmonis (Copepoda: Caligidae) under laboratory conditíons. $J$. Mar. Biol. Ass. U.K. 71: 425-436.

Maroni K, Steinshylla K, Willumsen FW. 1994. Lice cost the farming community more than 100 mill. NOK every year (In Norwegian). Norsk Fiskeoppdrett 7: 30-31.

Pike AW. 1989. Sea lice - Major pathogens of farmed Atlantic salmon. Parasitol. Today 5(9): 291-297.

Pike AW, Mordue AJ, Ritchie G. 1993. The development of Caligus elongatus Normann from hatehing to copepodid in relation to temperature. In: Boxshall G, Defaye D, eds. Pathogens of wild and farmed fish: sea lice. New York: Ellis Horwood, 51-60.

Ritchíe G, Mordue AJ, Pike AW, Rae GH. 1993. The reproductive output of Lepeophtheirus salmonis adult females in relation to seasonal variability of temperature and photoperiod, In: Boxshall G, Defaye D, eds. Pathogens of wild and farmed fish: sea lice. New York: Ellis Horwood, 153165.

Schram T. 1993. Supplementary descriptions of the developmental stages of Lepeophtheirus salmonis (Krøyer, 1837) (Copepoda:Caligidae) $\ln \times$ Boxshall G, Defaye D, eds. Pathogens of wild and farmed fish: sea lice. New York: Ellis Horwood, 30-47.

Skjermo J, Salvesen I, Øie G, Olsen Y, Vadstein O. 1997. Microbially matured water: a technique for selection of a non-opportunistic bacterial flora in water that may improve performance of marine larvae. Aquaculture International 5: 13-28.

Tully 0.1989 . The succession of generations and growth of the caligid copepod Caligus elongatus and Lepeophtheirus salmonis parasiting farmed Atlantic salmon smolts (Salmo salar L.). $J$ mar. biol. ass: U.K. 69; 279-287.

Wootten R, Smith JW, Needham EA. 1982. Aspects of the biology of the parasitic copepods Lepeophtheirus salmonis and Caligus elongatus on farmed salmonids and their treatment. Edinburgh: Proc. Roy. Soc. 81B: 185-197.

Received: 1 February 1999 